prof. dr. sc. Kristina Mijić

Ekonomski fakultet u Subotici, Univerzitet u Novom Sadu, Subotica, Republika Srbija

mijick@ef.uns.ac.rs

\title{
Dejan Jakšić
}

Ekonomski fakultet u Subotici, Univerzitet u Novom Sadu, Subotica, Republika Srbija

jaksicd@ef.uns.ac.rs

\section{PRAKSA REVIZIJE FINANCIJSKIH IZVEŠTAJA U REPUBLICI SRBIJI - STANJE I PERSPEKTIVE}

Primljen: 1. srpnja 2019.

Prihvaćen: 17. listopad 2019.

\section{Pregledni rad}

\section{Sažetak}

U radu je biti provedena analiza prakse revizije financijskih izvještaja kroz analizu performansi poslovanja revizorskih firmi. Istraživanjem su obuhvaćene sve revizorske firme koje posluju u periodu 2015-2017. godina u Republici Srbiji. U cilju ispitivanja performansi poslovanja revizorskih firmi analizirana je profitabilnost, zaduženost $i$ broj zaposlenih prema veličini revizorske firme $i$ pripadnosti međunarodnoj mreži. Rezultati istraživanja ukazuju kako mikro revizorske firme imaju problem sa profitabilnošću i prezaduženosti. Sa aspekta pripadnosti međunarodnoj mreži čak $80 \%$ zaposlenih se nalazi u ovim firmama, koje ostvaruju i bolju profitabilnost.

Ključne riječi: revizorske firme, performanse poslovanja.

JEL: M42

\section{UVOD}

Značajan faktor unapređenja kvaliteta cjelokupnog sustava financijskog izvještavanja i smanjenja rizika donošenja poslovnih odluka jeste revizija financijskih izvještaja. Revizija financijskih izvještaja ima za cilj izražavanje mišljenja o istinitosti i objektivnosti financijskih izvještaja i u današnje vrijeme financijski izvještaj zajedno sa revizijskim izvještajem predstavlja neraskidivu bazu 
poslovnog odlučivanja. Revizija financijskih izvještaja provodi se od strane neovisnih osoba, revizora, koji su organizirani u okviru revizorskih firmi. Iz kuta revizorske firme, osnovni cilj poslovanja poistovjećuje se sa ciljem poslovanja bilo kojeg drugog poduzeća. Dakle, iz kuta revizorske firme osnovni cilj poslovanja jeste dugoročno poslovanje na tržištu i ostvarivanje profita. Pored revizijskih usluga, revizorske firme prihode iz poslovanja stječu i po osnovu vršenja nerevizijskih usluga kao što su usluge poreznog savjetovanja, vođenja poslovnih knjiga, obračuna transfernih cijena i sl. Međutim, prilikom vršenja usluga revizije financijskih izvještaja revizorska firma mora prvenstveno da vodi računa o konceptu neovisnosti između revizorske firme i klijenta revizije. Za vlasnike i menadžere revizorskih firmi važno je da se kontinuirano mjere i analiziraju performanse poslovanja kako na razini pojedinačne revizorske firme, tako i na razini cjelokupnog tržišta revizorskih usluga. Indikatori performansi, odnosno indikatori poslovanja kao kvantitativni i kvalitativni pokazatelji poslovanja pomažu poduzećima u definiranju i mjerenju uspjeha u ostvarivanju svojih ciljeva.

Revizorske firme posluju u svetu i u razvijenim ekonomija već više od sto godina. U Republici Srbiji revizija kao profesija se može ocijeniti kao izuzetno mlada, obzirom da je revizija financijskih izvještaja prvi put zakonski regulirana sredinom devedesetih godina XX. stoljeća. I pored činjenice da nešto više od dvadeset godina je revizija financijskih izvještaja prisutna na prostorima Republike Srbije, poslovima revizije financijskih izvještaja bave se i tzv. ,velika četvorka“ u koju se ubrajaju Deloitte, PriceWaterhouseCoopers, Ernst\&Young i KPMG. Pored "velike četvorke” poslove revizije financijskih izvještaja realiziraju i druge revizorske firme koje su dio međunarodne mreže poslovanja iz revizije ili koje se poslovima revizije bave samo na razini Republike Srbije.

Osnovni cilj rada jeste da se analiziraju performanse poslovanja revizorskih firmi registriranih na teritoriji Republike Srbije u razdoblju 2015-2017. godina. Analiza performansi poslovanja od izuzetnog je značaja prije svega za vlasnike i menadžere revizorskih firmi kako bi sagledali efekte poslovnih odluka i kreirali buduće strategija razvoja na tržištu. Performanse poslovanja revizorskih firmi sagledane su sa aspekta broja zaposlenih, profitabilnosti i zaduženosti na razini revizorskih firmi razvrstanih prema veličini i pripadnosti međunarodnoj mreži poslovanja. Veličina revizorske firme sa aspekta kapaciteta, odnosno broja ovlaštenih revizora i revizora može biti ograničavajući faktor za pristup pojedinim segmentima revizorskog tržišta. Također, pripadnost međunarodnoj grupi poslovanja može kod potencijalnih klijenata koji također posluju u okviru međunarodne grupe biti odlučujući faktor izbora međunarodne revizorske firme. Osnovni cilj rada je dati odgovor na pitanje razlikuju li se performanse poslovanja revizorskih firmi značajno u ovisnosti od veličine revizorske firme ili u ovisnosti od pripadnosti međunarodnoj mreži. Rezultati istraživanja trebaju dati smjernice unapređenja performansi poslovanja revizorskih firmi kroz rast. Rast revizorskih firmi može se 
ostvariti po različitim osnovama kao što su: rast produktivnosti, povećanje prihoda od prodaje i kroz rast zaposlenih (opširnije vidjeti: Kolvereid, Amo, 2019).

Rezultati istraživanja treba da ukažu na stanje i perspektive poslovanja revizorskih firmi u Republici Srbiji. Za potrebu istraživanja korišteni su podaci registra poduzeća za reviziju Komore ovlaštenih revizora (Komora ovlaštenih revizora, 2019) i financijski izvještaji revizorskih firmi preuzetih iz baze Scoring (Scoring, 2019).

\section{PREGLED REVIZORSKIH FIRMI U REPUBLICI SRBIJI}

Profesija revizije financijskih izvještaja u Republici Srbiji prvi put je zakonski regulirana 1996. godine. Međutim, prva firma za realizaciju poslova neovisne revizije financijskih izvještaja je osnovana 1991. godine i bio je to Deloitte sa sjedištem u Beogradu. Danas za obavljanje poslova revizije financijskih izvještaja registrirano je 67 revizorski firmi. Pregled broja revizorskih firmi koje i danas posluju u periodu od 1991-2017. godina je dan na narednom prikazu.

Grafikon 1. Broj revizorskih firmi u Republici Srbiji prema osnivanju u razdoblju od 1991-2017. godine

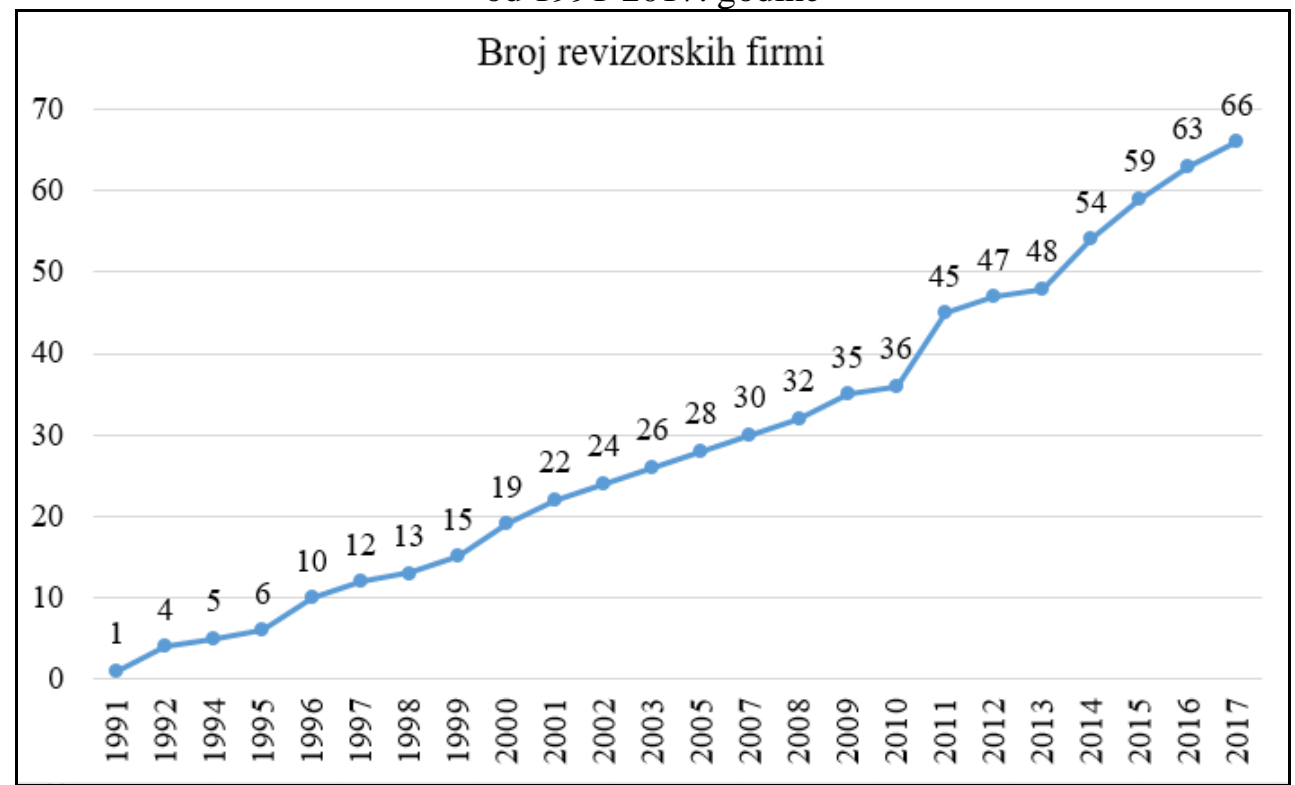

Izvor: Izrada autora

Uvjeti i način provođenja revizije financijskih izvještaja u Republici Srbiji su do lipnja 2013. godine bili regulirani Zakonom o računovodstvu i reviziji iz 2009. godine (Sl. glasnik RS, br. 46/06, 111/09 i 99/11), a potom Zakonom o reviziji (Sl. glasnik RS, br. 62/2013 i 30/2018). Prema članku 21. Zakona o reviziji, revizija je 
obvezna za redovne godišnje financijske izvještaje velikih i srednjih pravnih osoba, javnih društava u skladu sa zakonom kojim se uređuje tržište kapitala neovisno od njihove veličine, kao i svih poduzetnika čiji poslovni prihod ostvaren u prethodnoj poslovnoj godini prelazi 4.400 .000 eura u dinarskoj protuvrijednosti. Iako zakonom nije obvezno, ostala poduzeća mogu provoditi reviziju financijskih izvještaja, ako je to u interesu njihovog poslovanja. Novim Zakonom o reviziji izmijenjena je klasifikacija poduzeća na mikro, mala, srednja i velika na način da su se povećali kriteriji po pitanju prosječnog broja zaposlenih, poslovnih prihoda i prosječne poslovne imovine. Navedene izmijene utjecale su na prelazak značajnog broja poduzeća u nižu kategoriju, što za posljedicu ima smanjenje broja obveznika revizije od 2014. godine.

$\mathrm{U}$ postupku provođenja revizije financijskih izvještaja u Republici Srbiji primjenjuju se, pored odredbi Zakona, i Međunarodni standardi revizije. Ako se u toku provođenja postupka revizije financijskih izvještaja otkriju materijalno značajne radnje koje imaju karakteri kriminalnih djela, revizijska firma je u obvezi da o tome izvesti upravu poduzeća i nadležne državne organe. Također, revizijska firma je obvezna da sve uočene nedostatke u pogledu funkcioniranja sistema internih kontrola u vezi financijskog izvještavanja, kao i o svim drugim bitnim pitanjima izvješćuje upravu poduzeća klijenta revizije. Postupak revizije financijskih izvještaja poduzeća okončan je izdavanjem revizijskog mišljenja u formi revizijskog izvještaja skladu sa Međunarodnim standardima revizije. Revizijski izvještaj se predaje poduzeću klijentu revizije, koje je u obvezi da revizijski izvještaj zajedno sa financijskim izvještajem dostavi Agenciji za privredne registre. Financijski izvještaj zajedno sa revizijskim izvještajem javno je dostupan na sajtu Agencije za privredne registre.

Jedna revizijska firma može obavljati reviziju financijskih izvještaja jednog poduzeća najviše u toku sedam uzastopnih godina. Nakon isteka navedenog perioda, revizijska firma može obavljati reviziju, ukoliko reviziju vrši drugi ovlašteni revizor. Ako u revizijskoj firmi nema zaposlen drugi ovlašteni revizor, onda reviziju financijskih izvještaja mora obavljati druga revizijska firma, uslijed mogućnosti narušavanja koncepta neovisnosti revizijske firme. Pored toga, člankom 35. Zakon o reviziji definirane su i još neke situacije u kojima se narušava neovisnost revizijske firme i prema kojima revizijska firma ne može da obavlja reviziju kod poduzeća:

- u kojem ima udjele ili dionice,

- koje je vlasnik udjela ili dionica revizijske firme,

- ako je revizijska firma pružala poduzeću potencijalnom klijentu nerevizijske usluge (priprema i vođenje poslovnih knjiga, sastavljanje financijskih izvještaja, procjena vrijednosti kapitala, imovine i sl.),

- ako je revizijska firma povezana sa poduzećem potencijalnim klijentom na način da se utječe na neovisnosti i nepristranosti obavljanja revizije. 
U Republici Srbiji je do sada je zabilježeno 6 revizorskih firmi kojima je prestala da važi dozvola za obavljanje poslova revizije financijskih izvještaja. Kao razlog najčešće se javlja nepostojanje ovlaštenog revizora za obavljanje poslova revizije. Revizorske firme u Republici Srbiji se u većini slučaja registriraju na području grada Beograda (približno $80 \%$ ), dok oko $10 \%$ je registrirano na području grada Novog Sada i po jedna revizorska firma u ostalim gradovima (tabela 1).

Promatrajući revizorske firme prema veličini uočava se dominantnost mikro revizorskih firmi (75\%). Pored mikro revizorskih firmi prisutne su male revizorske firme $(20 \%)$ i srednje revizorske firme (5\%). Od „velike četvorke“ status srednjih revizorskih firmi imaju Deloitte, Ernst\&Young i KPMG. U 2011. godini 4 revizorske firme imale su status srednjih poduzeća (opširnije vidjeti: Jakšić i suradnici, 2012).

Tablica 1. Raspored revizijskih firmi prema veličini u razdoblju 2015-2017. godina

\begin{tabular}{|c|c|c|c|}
\hline Veličina poduzeća & $\mathbf{2 0 1 5}$ & $\mathbf{2 0 1 6}$ & $\mathbf{2 0 1 7}$ \\
\hline Malo & 13 & 12 & 13 \\
\hline Mikro & 43 & 47 & 50 \\
\hline Srednje & 2 & 3 & 3 \\
\hline Ukupno & $\mathbf{5 8}$ & $\mathbf{6 2}$ & $\mathbf{6 6}$ \\
\hline
\end{tabular}

Izvor: Izrada autora

Iako je tržište revizije u Republici Srbiji relativno malo, skoro 1/3 revizorskih firmi koje posluju su članice međunarodne mreže poslovanja (tabela 3). Poslovanje u okviru međunarodne mreže doprinosi prijenosu znanja i iskustva, razvoju profesije, a stvara mogućnost i za stjecanje boljeg tržišnog položaja.

Tablica 2. Raspored revizijskih firmi prema pripadnosti međunarodnoj mreži u razdoblju 2015-2017. godina

\begin{tabular}{|l|r|r|r|}
\hline Međunarodna mreža & $\mathbf{2 0 1 5}$ & $\mathbf{2 0 1 6}$ & $\mathbf{2 0 1 7}$ \\
\hline $\mathrm{Da}$ & 22 & 23 & 24 \\
\hline $\mathrm{Ne}$ & 36 & 39 & 42 \\
\hline Ukupno & $\mathbf{5 8}$ & $\mathbf{6 2}$ & $\mathbf{6 6}$ \\
\hline
\end{tabular}

Izvor: Izrada autora

Razvoj profesije revizije u Republici Srbiji praćen je i rastom ovlaštenih revizora. Prema podacima Komore ovlaštenih revizora u Republici Srbiji ima trenutno 308 licenciranih ovlaštenih revizora, dok je prisutno i 39 revizora kojima je istekla licenca (Komora ovlaštenih revizora, 2019). U 2010. godini broj ovlaštenih revizora iznosio je 181 (opširnije vidjeti: Jakšić i suradnici, 2010). 


\section{METODOLOGIJA ISTRAŽIVANJA I OPIS UZORKA}

Indikatori poslovanja revizorskih firmi obuhvaćaju širok spektar pokazatelja kao što su pokazatelji: broj zaposlenih, broj revizora, povrat na imovinu, stupanj zaduženosti, prihod od pružanja usluga, broj klijenata revizije, broj gradova u kojima revizorska firma ima urede i sl. (opširnije vidjeti: Holm, Warming-Rasmussen, 2008, Grant, 2010, Mijić, Jakšić, Vuković, 2014). Osnovni cilj rada je sagledati praksu poslovanja revizorskih firmi u Republici Srbiji u periodu 2015-2017. godina. S obzirom na ograničenu dostupnost podataka, poslovanje revizorskih firmi analizirano je sa aspekata sljedećih pokazatelja performansi poslovanja:

- broj zaposlenih,

- profitabilnost,

- zaduženost.

Broj zaposlenih, prije svega broj zaposlenih revizora može imati utjecaj na kvalitetu revizije (opširnije vidjeti: Gul, 2017, Goodwin, Wu, 2016). Kvaliteta revizijskih usluga utječe na profitabilnost u budućem periodu poslovanja. Profitabilnost kao mjera uspješnosti poslovanja poduzeća analizirana je na osnovu povrata na ukupna sredstva. Povrat na ukupna sredstva ukazuje na moć zarade poduzeća (Rodić i suradnici, 2017). Povrat na ukupna sredstva iskazuje se kao odnos neto rezultata i prosječnih ukupnih sredstava.

Zaduženost ukazuje na strukturu izvora financiranja revizorskih firmi. Za potrebu istraživanja zaduženost je mjerena i analizirana na osnovu koeficijenta zaduženosti koji predstavlja odnos duga i ukupnih sredstava revizorske firme.

Istraživanje je bazirano na razini svih revizorskih firmi koje posluju u razdoblju 2015-2017. godina. U 2015. godini broj revizorskih firmi je bio 58, u 2016. godini 62, a u 2017. godini 66. Za potrebu istraživanja korišteni su javno dostupni podaci sa web stranice Komore ovlaštenih revizora, kao i financijski izvještaji i podaci o poslovanju revizorskih firmi preuzetih iz baze Scoring. Revizorske firme su podijeljene sa dva aspekta i to prema:

- veličini,

- pripadnosti međunarodnoj mreži.

U prvom djelu istraživanja deskriptivna analiza broja zaposlenih, profitabilnosti i zaduženosti je provedena i to sa aspekta rasporeda revizorskih firmi prema veličini i prema pripadnosti međunarodnoj mreži poslovanja. U drugom djelu istraživanja ispitano je postojanje i značajnost razlika u performansama poslovanja na razini revizorskih firmi sa navedena dva aspekta. S obzirom da postoje tri grupe prema veličini revizorskih firmi postojanje razlika u pojedinim performansama poslovanja testirano je primjenom statističkog testa Anova, dok je postojanje razlika u pojedinačnim performansama na razini grupa pripadnosti međunarodnoj mreži 
testirano primjenom statističkog testa Student t-test. Analiza podataka i rezultata realizirana je statističkom programu SPSS verzija 20 (prema: Beins, McCarthy, 2012).

\section{REZULTATI ISTRAŽIVANJA}

Analiza zaposlenosti u profesiji revizije ukazuje na ukupan porast broja zaposlenih u razdoblju 2015-2017. godina. U 2015. godini 1.204 zaposlenih je bilo u revizorskim firmama, dok u 2017. godini broj zaposlenih iznosio je 1.411. U promatranom razdoblju broj zaposlenih je porastao za oko 17\%. Analiza zaposlenosti prema veličini revizorske firme ukazuje na rast broja zaposlenih na razini mirko i srednjih poduzeća, dok se broj zaposlenih na razini malih revizorskih firmi u 2016. godini smanjuje, zatim bilježi tendenciju rasta u 2017. godini ali i dalje ispod nivoa broja zaposlenih koji je bio u 2015. godini (tabela 3). Promatrajući raspored zaposlenih prema revizorskim firmama koje pripadaju međunarodnoj mreži, uočava se da čak $80 \%$ zaposlenih radi u okviru revizorskih firmi članica međunarodne mreže (tabela 4).

Tablica 3. Broj zaposlenih prema veličini revizijske firme u razdoblju 2015-2017. godina

\begin{tabular}{|l|r|r|r|}
\hline Veličina & $\mathbf{2 0 1 5}$ & $\mathbf{2 0 1 6}$ & $\mathbf{2 0 1 7}$ \\
\hline Malo & 578 & 433 & 469 \\
\hline Mikro & 250 & 275 & 299 \\
\hline Srednje & 376 & 583 & 643 \\
\hline Ukupno & $\mathbf{1 2 0 4}$ & $\mathbf{1 2 9 1}$ & $\mathbf{1 4 1 1}$ \\
\hline
\end{tabular}

Izvor: Izrada autora

Tablica 4. Broj zaposlenih prema pripadnosti međunarodnoj mreži u razdoblju 2015-2017. godina

\begin{tabular}{|l|r|r|r|}
\hline Međunarodna mreža & $\mathbf{2 0 1 5}$ & $\mathbf{2 0 1 6}$ & $\mathbf{2 0 1 7}$ \\
\hline $\mathrm{Da}$ & 967 & 1032 & 1141 \\
\hline $\mathrm{Ne}$ & 237 & 259 & 270 \\
\hline Ukupno & $\mathbf{1 2 0 4}$ & $\mathbf{1 2 9 1}$ & $\mathbf{1 4 1 1}$ \\
\hline
\end{tabular}

Izvor: Izrada autora

Profitabilnost revizorskih firmi u razdoblju 2015-2017. godina je dosta fluktuirajućeg karaktera. Prosječna profitabilnost u 2015. godini je zadovoljavajuća i iznosi u prosjeku 11,05\%. Međutim, u 2016. godini u prosjeku revizorske firme nisu profitabilne, u prosjeku posluju sa gubitkom. U 2017. godini prosječna profitabilnost iznosi svega $0,35 \%$. U 2017. godini ni jedna grupa revizorskih firmi prema veličini ne ispunjava referentnu vrijednost povrata na ukupna sredstva od $10 \%$. Poslovanje u okviru međunarodne mreže osigurava bolju profitabilnost u 2016. i 2017. godini. 
Tablica 5. Povrat na ukupna sredstva prema veličini revizijske firme u razdoblju 2015-2017. godina

\begin{tabular}{|l|r|r|r|}
\hline Veličina & $\mathbf{2 0 1 5}$ & $\mathbf{2 0 1 6}$ & $\mathbf{2 0 1 7}$ \\
\hline Malo & 0,1609 & 0,0875 & 0,0736 \\
\hline Mikro & 0,0955 & $-0,1069$ & $-0,0181$ \\
\hline Srednje & 0,1050 & 0,1195 & 0,0599 \\
\hline Ukupno & $\mathbf{0 , 1 1 0 5}$ & $\mathbf{- 0 , 0 5 8 3}$ & $\mathbf{0 , 0 0 3 5}$ \\
\hline
\end{tabular}

Izvor: Izrada autora

Tablica 6. Povrat na ukupna sredstva prema pripadnosti međunarodnoj mreži u razdoblju 2015-2017. godina

\begin{tabular}{|l|r|r|r|}
\hline Međunarodna mreža & $\mathbf{2 0 1 5}$ & $\mathbf{2 0 1 6}$ & $\mathbf{2 0 1 7}$ \\
\hline $\mathrm{Da}$ & 0,0834 & 0,0171 & 0,0373 \\
\hline $\mathrm{Ne}$ & 0,1270 & $-0,1028$ & $-0,0158$ \\
\hline Ukupno & $\mathbf{0 , 1 1 0 5}$ & $\mathbf{- 0 , 0 5 8 3}$ & $\mathbf{0 , 0 0 3 5}$ \\
\hline
\end{tabular}

Izvor: Izrada autora

Analiza zaduženosti ukazuje da se revizorske firme u Republici Srbiji u većem dijelu financiraju iz tuđih izvora. Potreban kapital za osnivanje revizorskih firmi iznosi svega 100 dinara. U periodu 2015-2017. godina zaduženost ima tendenciju rasta. Prosječan koeficijent zaduženosti u 2015. godini iznosio je 0,6028, a u 2017. godini 0,8783 . Male revizorske firme nemaju problem sa zaduženosti, dok mikro revizorske firme imaju značajne poteškoće sa izvorima financiranja i profitabilnošću. Na nivou mikro revizorskih firmi prisutne su firme koje imaju gubitak iznad visine kapitala. Zaduženost revizorskih firmi koje su članice međunarodne mreže i koje nisu je na relativno višem nivou od zaduženost revizorskih firmi koje nisu članice međunarodne mreže.

Tablica 9. Koeficijent zaduženosti revizijskih firmi prema veličini u periodu 20152017. godina

\begin{tabular}{|l|r|r|r|}
\hline Veličina & $\mathbf{2 0 1 5}$ & $\mathbf{2 0 1 6}$ & $\mathbf{2 0 1 7}$ \\
\hline Malo & 0,3426 & 0,3387 & 0,4092 \\
\hline Mikro & 0,6712 & 0,9488 & 1,0059 \\
\hline Srednje & 0,8241 & 0,7317 & 0,7840 \\
\hline Ukupno & $\mathbf{0 , 6 0 2 8}$ & $\mathbf{0 , 8 2 0 2}$ & $\mathbf{0 , 8 7 8 3}$ \\
\hline
\end{tabular}

Izvor: Izrada autora 
Tablica 10. Koeficijent zaduženosti revizijskih firmi prema pripadnosti međunarodnoj mreži u periodu 2015-2017. godina

\begin{tabular}{|l|r|r|r|}
\hline Međunarodna mreža & $\mathbf{2 0 1 5}$ & $\mathbf{2 0 1 6}$ & $\mathbf{2 0 1 7}$ \\
\hline $\mathrm{Da}$ & 0,6450 & 0,8486 & 0,9050 \\
\hline $\mathrm{Ne}$ & 0,5771 & 0,8034 & 0,8630 \\
\hline Ukupno & $\mathbf{0 , 6 0 2 8}$ & $\mathbf{0 , 8 2 0 2}$ & $\mathbf{0 , 8 7 8 3}$ \\
\hline
\end{tabular}

Izvor: Izrada autora

U cilju istraživanja značajnost razlika u pojedinačnim performansama poslovanja između mikro, malih i srednjih revizorskih firmi proveden je test ANOVA. U tablici 11 predstavljena je deskriptivna statistika za revizorske firme prema veličini u razdoblju 2015-2017. godina.

Tablica 11. Deskriptivna statistika pojedinačnih performansi poslovanja revizorskih firmi prema veličini

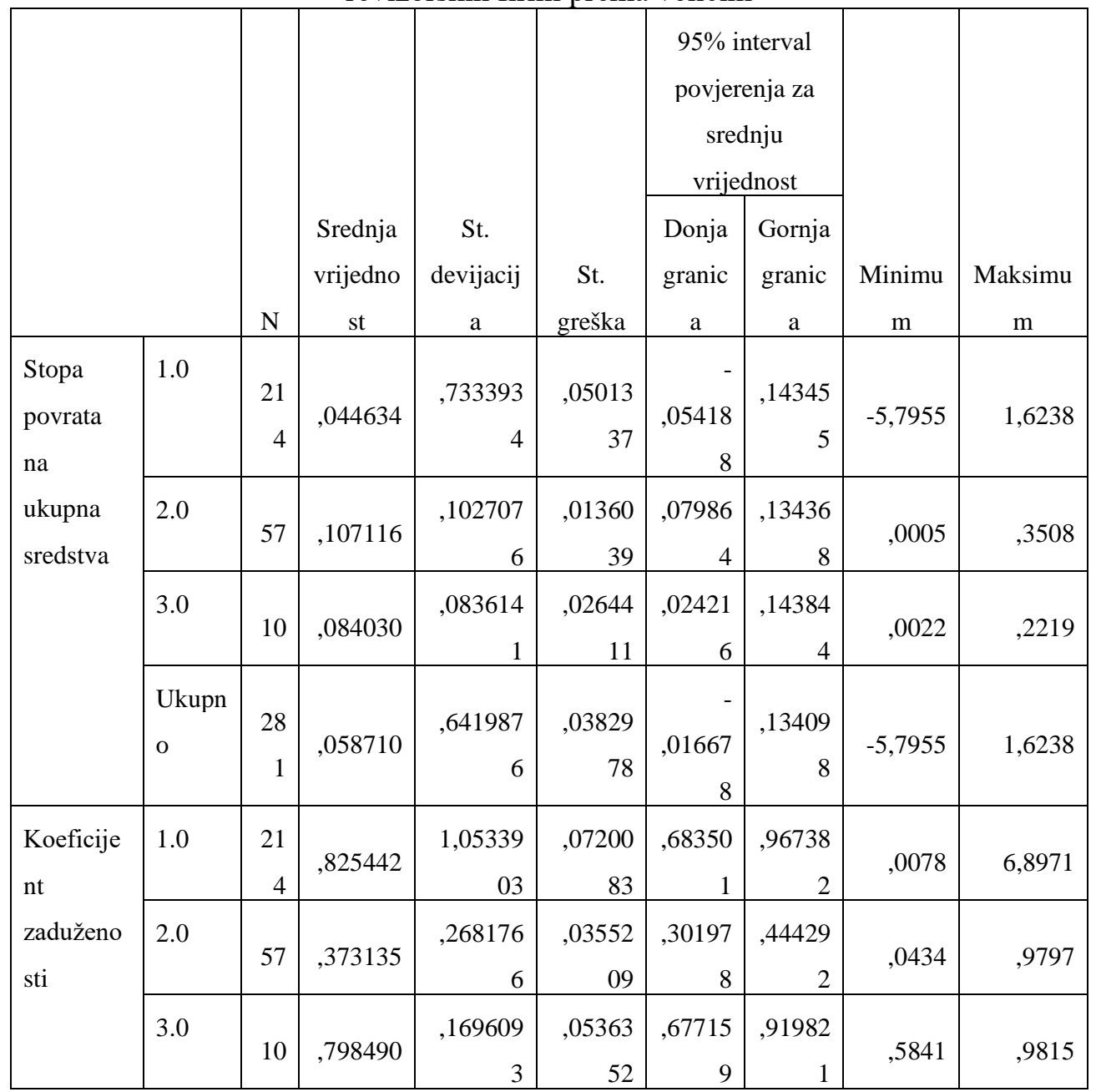




\begin{tabular}{|c|c|c|c|c|c|c|c|c|c|}
\hline & $\begin{array}{l}\text { Ukupn } \\
\text { o }\end{array}$ & $\begin{array}{r}28 \\
1 \\
\end{array}$ & ,732733 & $\begin{array}{r}944705 \\
3 \\
\end{array}$ & $\begin{array}{r}, 05635 \\
64 \\
\end{array}$ & $\begin{array}{r}62179 \\
7 \\
\end{array}$ & $\begin{array}{r}84366 \\
9 \\
\end{array}$ & ,0078 & 6,8971 \\
\hline \multirow{4}{*}{$\begin{array}{l}\text { Broj } \\
\text { zaposleni } \\
\text { h }\end{array}$} & 1.0 & $\begin{array}{r}21 \\
4 \\
\end{array}$ & 6,093 & 4,7768 & ,3265 & 5,450 & 6,737 & ,0 & 28,0 \\
\hline & 2.0 & 57 & 39,807 & 36,1803 & 4,7922 & 30,207 & 49,407 & 12,0 & 162,0 \\
\hline & 3.0 & 10 & 199,500 & 17,1286 & 5,4165 & $\begin{array}{r}187,24 \\
7 \\
\end{array}$ & $\begin{array}{r}211,75 \\
3 \\
\end{array}$ & 176,0 & 226,0 \\
\hline & $\begin{array}{l}\text { Ukupn } \\
\text { o }\end{array}$ & $\begin{array}{r}28 \\
1 \\
\end{array}$ & 19,815 & 40,8283 & 2,4356 & 15,021 & 24,609 & ,0 & 226,0 \\
\hline
\end{tabular}

1 - mikro poduzeća

2 - mala poduzeća

3 - srednja poduzeća

Izvor: Izrada autora

Rezultati testa ANOVA ukazuju da na razini pojedinačnih performansi između revizorskih firmi prema veličini postoji značajna razlika u broju zaposlenih i koeficijentu zaduženosti. Razlike između revizorskih firmi prema veličini u razini stope povrata na ukupna sredstva iako su prisutne nisu statistički značajne.

Tablica 12. Rezultati testa ANOVA

\begin{tabular}{|l|l|r|r|r|r|r|}
\hline \multicolumn{2}{|l|}{} & \multicolumn{1}{|c|}{$\begin{array}{r}\text { Broj } \\
\text { Suma } \\
\text { stupanj } \\
\text { slobod } \\
\text { e }\end{array}$} & $\begin{array}{c}\text { Kvadrat } \\
\text { sredine }\end{array}$ & \multicolumn{1}{c|}{ F } & $\begin{array}{c}\text { Značajnos } \\
\text { t (p) }\end{array}$ \\
\hline $\begin{array}{l}\text { Stopa } \\
\text { povrata } \\
\text { na } \\
\text { ukupna } \\
\text { sredstva }\end{array}$ & $\begin{array}{l}\text { Izmeđ } \\
\text { grupa }\end{array}$ &, 182 & 2 &, 091 &, 220 &, 803 \\
\hline $\begin{array}{l}\text { Koeficijent } \\
\text { zaduženost } \\
\text { i }\end{array}$ & $\begin{array}{l}\text { Izmeđ } \\
\text { urupa }\end{array}$ & 9,253 & 2 & 4,627 & 5,345 &, $\mathbf{0 0 5}$ \\
\hline $\begin{array}{l}\text { Broj } \\
\text { zaposlenih }\end{array}$ & $\begin{array}{l}\text { Izmeđ } \\
\text { u } \\
\text { grupa }\end{array}$ & 385940,86 & 9 & 192970,43 & 663,88 & \\
\hline
\end{tabular}

Izvor: Izrada autora 
U tablici 13. prezentirani su razlike i sličnosti u performansama poslovanja na razini pojedinih grupa revizorskih firmi prema veličini. U broju zaposlenih razlika je značajna između sve tri grupe revizorskih firmi. U koeficijentu zaduženosti, također, postoji značajna razlika između mikro i malih revizorskih firmi. S obzirom da je dobivena vrijednost $\mathrm{p}$ (značajnost) manja od 0,05 razlike su signifikantne na razini od $5 \%$.

Tablica 13. Sličnosti i razlike u pojedinačnim performansama poslovanja revizorskih firmi prema veličini

\begin{tabular}{|c|c|c|c|c|c|c|c|}
\hline \multirow[b]{2}{*}{ Varijabla } & \multirow{2}{*}{$\begin{array}{l}\text { (I) } \\
\text { Veličin } \\
\text { a }\end{array}$} & \multirow{2}{*}{$\begin{array}{l}\text { (J) } \\
\text { Veličin } \\
\text { a }\end{array}$} & \multirow[b]{2}{*}{$\begin{array}{l}\text { Razlika } \\
\text { sredine }\end{array}$} & \multirow[b]{2}{*}{$\begin{array}{c}\text { St. } \\
\text { greška }\end{array}$} & \multirow[b]{2}{*}{$\begin{array}{c}\text { Značajno } \\
\text { st }\end{array}$} & \multicolumn{2}{|c|}{$\begin{array}{c}95 \% \text { interval } \\
\text { povjerenja }\end{array}$} \\
\hline & & & & & & $\begin{array}{c}\text { Donja } \\
\text { granica }\end{array}$ & $\begin{array}{l}\text { Gornja } \\
\text { granica }\end{array}$ \\
\hline \multirow{6}{*}{$\begin{array}{l}\text { Stopa } \\
\text { povrata } \\
\text { na ukupna } \\
\text { sredstva }\end{array}$} & \multirow[t]{2}{*}{1.0} & 2.0 & $\begin{array}{r}- \\
, 062482 \\
1 \\
\end{array}$ & $\begin{array}{r}.095957 \\
8\end{array}$ & .515 & $\begin{array}{r}- \\
.251378\end{array}$ & .126414 \\
\hline & & 3.0 & $\begin{array}{r}- \\
\text {,039396 } \\
4\end{array}$ & $\begin{array}{r}.208284 \\
5\end{array}$ & .850 & .449411 & .370619 \\
\hline & \multirow[t]{2}{*}{2.0} & 1.0 & $\begin{array}{r}, 062482 \\
1 \\
\end{array}$ & $\begin{array}{r}.095957 \\
8 \\
\end{array}$ & .515 & $\begin{array}{r}- \\
.126414 \\
\end{array}$ & .251378 \\
\hline & & 3.0 & $\begin{array}{r}023085 \\
8 \\
\end{array}$ & $\begin{array}{r}.220719 \\
0 \\
\end{array}$ & .917 & $\begin{array}{r}- \\
.411407 \\
\end{array}$ & .457579 \\
\hline & \multirow[t]{2}{*}{3.0} & 1.0 & $\begin{array}{r}, 039396 \\
4 \\
\end{array}$ & $\begin{array}{r}.208284 \\
5 \\
\end{array}$ & .850 & $\begin{array}{r}- \\
.370619 \\
\end{array}$ & .449411 \\
\hline & & 2.0 & $\begin{array}{r}- \\
, 023085 \\
8 \\
\end{array}$ & $\begin{array}{r}.220719 \\
0\end{array}$ & .917 & .457579 & .411407 \\
\hline \multirow{4}{*}{$\begin{array}{l}\text { Koeficije } \\
\text { nt } \\
\text { zaduženos } \\
\text { ti }\end{array}$} & \multirow[t]{2}{*}{1.0} & 2.0 & $\begin{array}{r}452306 \\
5^{*}\end{array}$ & $\begin{array}{r}.138675 \\
5 \\
\end{array}$ & .001 & .179319 & .725294 \\
\hline & & 3.0 & $\begin{array}{r}026951 \\
6 \\
\end{array}$ & $\begin{array}{r}.301007 \\
0 \\
\end{array}$ & .929 & $\begin{array}{r}- \\
.565591 \\
\end{array}$ & .619494 \\
\hline & \multirow[t]{2}{*}{2.0} & 1.0 & $\begin{array}{r}- \\
, 452306 \\
5^{*}\end{array}$ & $\begin{array}{r}.138675 \\
5 \\
\end{array}$ & .001 & $\begin{array}{r}- \\
.725294\end{array}$ & $\begin{array}{r}- \\
.179319\end{array}$ \\
\hline & & 3.0 & - & .318977 & .183 & - & .202562 \\
\hline
\end{tabular}




\begin{tabular}{|c|c|c|c|c|c|c|c|}
\hline & & & $\begin{array}{r}425354 \\
9\end{array}$ & 1 & & $\begin{array}{r}1.05327 \\
2\end{array}$ & \\
\hline & \multirow[t]{2}{*}{3.0} & 1.0 & $\begin{array}{r}- \\
626951 \\
6\end{array}$ & $\begin{array}{r}.301007 \\
0\end{array}$ & .929 & $\begin{array}{r}- \\
.619494\end{array}$ & .565591 \\
\hline & & 2.0 & $\begin{array}{r}425354 \\
9\end{array}$ & $\begin{array}{r}.318977 \\
1\end{array}$ & .183 & $\begin{array}{r}- \\
.202562\end{array}$ & $\begin{array}{r}1.05327 \\
2\end{array}$ \\
\hline \multirow{6}{*}{$\begin{array}{l}\text { Broj } \\
\text { zaposleni } \\
\text { h }\end{array}$} & \multirow[t]{2}{*}{1.0} & 2.0 & $\begin{array}{r}- \\
33,7136^{*}\end{array}$ & 2.5412 & .000 & -38.716 & -28.711 \\
\hline & & 3.0 & $\begin{array}{r}- \\
193,406 \\
5^{*} \\
\end{array}$ & 5.5159 & .000 & 204.265 & $\begin{array}{r}- \\
182.548\end{array}$ \\
\hline & \multirow[t]{2}{*}{2.0} & 1.0 & $33,7136^{*}$ & 2.5412 & .000 & 28.711 & 38.716 \\
\hline & & 3.0 & $\begin{array}{r}- \\
159,693 \\
0^{*}\end{array}$ & 5.8452 & .000 & 171.199 & 148.187 \\
\hline & \multirow[t]{2}{*}{3.0} & 1.0 & $\begin{array}{r}193,406 \\
5^{*}\end{array}$ & 5.5159 & .000 & 182.548 & 204.265 \\
\hline & & 2.0 & $\begin{array}{r}159,693 \\
0^{*}\end{array}$ & 5.8452 & .000 & 148.187 & 171.199 \\
\hline
\end{tabular}

Izvor: Izrada autora

Deskriptivna statistika za pojedinačne performanse na razini revizorskih firmi sa aspekta pripadnosti međunarodnoj mreži su dane u tablicama 14. i 15.

Tablica 14. Deskriptivna statistika pojedinih performansi poslovanja revizorskih firmi koje su članice međunarodne mreže

\begin{tabular}{|l|r|r|r|r|r|}
\hline & Broj & Minimum & Maksimum & $\begin{array}{c}\text { Srednja } \\
\text { vrijednost }\end{array}$ & $\begin{array}{c}\text { St. } \\
\text { devijacija }\end{array}$ \\
\hline $\begin{array}{l}\text { Stopa povrata na } \\
\text { ukupna sredstva }\end{array}$ & 99 & $-2,2319$ & 1,2378 &, 071537 &, 4177342 \\
\hline $\begin{array}{l}\text { Koeficijent } \\
\text { zaduženost }\end{array}$ & 99 &, 0434 & 6,8971 &, 768681 & 1,0095701 \\
\hline Broj zaposlenih & 99 & 1,0 & 226,0 & 44,152 & 61,1513 \\
\hline
\end{tabular}

Izvor: Izrada autora 
Tablica 15. Deskriptivna statistika pojedinih performansi poslovanja revizorskih firmi koje nisu članice međunarodne mreže

\begin{tabular}{|l|r|r|r|r|r|}
\hline & Broj & Minimum & Maksimum & $\begin{array}{c}\text { Srednja } \\
\text { vrjednost }\end{array}$ & \multicolumn{1}{c|}{$\begin{array}{c}\text { St. } \\
\text { devijacija }\end{array}$} \\
\hline $\begin{array}{l}\text { Stopa povrata na } \\
\text { ukupna sredstva }\end{array}$ & 182 & $-5,7955$ & 1,6238 &, 051732 &, 7368558 \\
\hline $\begin{array}{l}\text { Koeficijent } \\
\text { zaduženost }\end{array}$ & 182 &, 0078 & 6,7727 &, 713180 &, 9097654 \\
\hline Broj zaposlenih & 182 &, 0 & 46,0 & 6,577 & 7,3388 \\
\hline
\end{tabular}

Izvor: Izrada autora

Rezultati Student t-testa ukazuju da postoje razlike u broju zaposlenih između revizorskih firmi članica prema pripadnosti međunarodnoj mreži. Iako postoje razlike u profitabilnosti i zaduženosti između revizorski firmi članica međunarodne mreže, razlike nisu statistički značajne.

Tabela 16. Rezultati Student t-testa

\begin{tabular}{|c|c|c|c|c|c|c|c|c|c|c|}
\hline & \multicolumn{2}{|c|}{$\begin{array}{c}\text { Levinov } \\
\text { test } \\
\end{array}$} & \multicolumn{7}{|c|}{ t-test } \\
\hline & & \multirow[b]{2}{*}{$\mathrm{F}$} & \multirow[b]{2}{*}{ 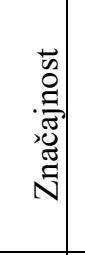 } & \multirow[b]{2}{*}{$\mathrm{t}$} & \multirow{2}{*}{ 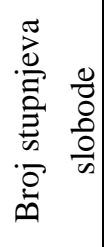 } & \multirow[b]{2}{*}{ 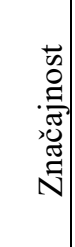 } & \multirow{2}{*}{ 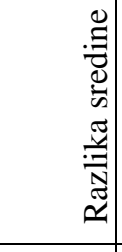 } & \multirow[b]{2}{*}{ 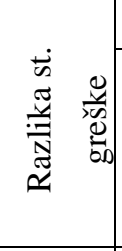 } & \multicolumn{2}{|c|}{$95 \%$} \\
\hline & & & & & & & & & 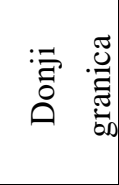 & 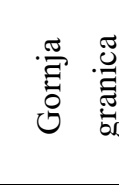 \\
\hline \multirow{2}{*}{$\begin{array}{l}\text { Stopa } \\
\text { povrata } \\
\text { na } \\
\text { ukupna } \\
\text { sredstva }\end{array}$} & $\begin{array}{l}\text { Varija } \\
\text { nce su } \\
\text { jednak } \\
\text { e }\end{array}$ & 1,963 & $\begin{array}{r}, 16 \\
2\end{array}$ & $\begin{array}{r}, 24 \\
7\end{array}$ & 279 & $\begin{array}{r}, 80 \\
5\end{array}$ & $\begin{array}{r}01980 \\
50\end{array}$ & $\begin{array}{r}, 08030 \\
75\end{array}$ & $\begin{array}{r}13828 \\
06\end{array}$ & $\begin{array}{r}17789 \\
05\end{array}$ \\
\hline & $\begin{array}{l}\text { Varija } \\
\text { nce } \\
\text { nisu } \\
\text { jednak } \\
\text { e }\end{array}$ & & & $\begin{array}{r}, 28 \\
7\end{array}$ & $\begin{array}{r}278,5 \\
04\end{array}$ & $\begin{array}{r}, 77 \\
4\end{array}$ & $\begin{array}{r}, 01980 \\
50\end{array}$ & $\begin{array}{r}06889 \\
07\end{array}$ & $\begin{array}{r}11580 \\
76\end{array}$ & $\begin{array}{r}15541 \\
75\end{array}$ \\
\hline
\end{tabular}




\begin{tabular}{|c|c|c|c|c|c|c|c|c|c|c|}
\hline \multirow[t]{2}{*}{$\begin{array}{l}\text { Koeficij } \\
\text { ent } \\
\text { zadužen } \\
\text { osti }\end{array}$} & $\begin{array}{l}\text { Varija } \\
\text { nce su } \\
\text { jednak } \\
\text { e }\end{array}$ & ,277 & $\begin{array}{r}, 59 \\
9\end{array}$ & $\begin{array}{r}47 \\
0\end{array}$ & 279 & $\begin{array}{r}63 \\
9\end{array}$ & $\begin{array}{r}05550 \\
11\end{array}$ & $\begin{array}{r}11814 \\
12\end{array}$ & $\begin{array}{r}- \\
, 17706 \\
02\end{array}$ & $\begin{array}{r}, 28806 \\
25\end{array}$ \\
\hline & $\begin{array}{l}\text { Varija } \\
\text { nce } \\
\text { nisu } \\
\text { jednak } \\
\text { e }\end{array}$ & & & $\begin{array}{r}, 45 \\
6\end{array}$ & $\begin{array}{r}184,2 \\
36\end{array}$ & $\begin{array}{r}64 \\
9\end{array}$ & $\begin{array}{r}05550 \\
11\end{array}$ & $\begin{array}{r}12183 \\
15\end{array}$ & $\begin{array}{r}- \\
, 18486 \\
32\end{array}$ & $\begin{array}{r}29586 \\
55\end{array}$ \\
\hline \multirow[t]{2}{*}{$\begin{array}{l}\text { Broj } \\
\text { zaposlen } \\
\text { ih }\end{array}$} & $\begin{array}{l}\text { Varija } \\
\text { nce su } \\
\text { jednak } \\
\text { e } \\
\end{array}$ & $\begin{array}{r}169,0 \\
25\end{array}$ & $\begin{array}{r}, 00 \\
0\end{array}$ & $\begin{array}{r}8,1 \\
94\end{array}$ & 279 & $\begin{array}{r}, 00 \\
0\end{array}$ & $\begin{array}{r}37,574 \\
6\end{array}$ & 4,5858 & $\begin{array}{r}28,547 \\
4\end{array}$ & $\begin{array}{r}46,601 \\
8\end{array}$ \\
\hline & $\begin{array}{l}\text { Varija } \\
\text { nce } \\
\text { nisu } \\
\text { jednak } \\
\text { e }\end{array}$ & & & $\begin{array}{r}6,0 \\
90\end{array}$ & $\begin{array}{r}99,53 \\
8\end{array}$ & $\begin{array}{r}, 00 \\
0\end{array}$ & $\begin{array}{r}37,574 \\
6\end{array}$ & 6,1700 & $\begin{array}{r}25,332 \\
9\end{array}$ & $\begin{array}{r}49,816 \\
3\end{array}$ \\
\hline
\end{tabular}

Izvor: Izrada autora

\section{ZAKLJUČAK}

Tržište revizije financijskih izvještaj u Republici Srbiji po pitanju broja obveznika revizije se smanjuje. Razlog tome je promjena zakonske regulative u pogledu klasifikacije poduzeća prema veličini i prelazak značajnog broja poduzeća u kategorije koje nisu obveznici godišnje revizije financijskih izvještaja. Također, prisutan je trend prelaska dioničarskih društava $u$ društva sa ograničenom odgovornošću. Međutim i pored ovakvih trendova prisutan je porast broja revizorskih firmi kao i porast zaposlenih u ovom sektoru. Navedeni trendovi na tržištu revizije u Republici Srbiji utjecali su na ostvarivanje lošijih performansi poslovanja. Naime, profitabilnost u 2015. godini je bila na zadovoljavajućoj razini. U 2016. godini čak 11\% revizorskih firmi posluje sa neto gubitkom, što utječe i na prosječnu neprofitabilnost revizorskog sektora. Prosječna profitabilnost u 2017. godini bilježi trend rast u odnosu na 2016. godinu, ali je prosječan povrat na ukupnu sredstva ispod $1 \%$. Po pitanju zaduženosti revizorske firme imaju problem sa optimalnom strukturom financiranja s obzirom da u 2017. godini koeficijent zaduženosti iznosi čak $87 \%$. 
Promatrajući razlike u performansama poslovanja između mikro, malih i srednjih revizorskih firmi, uočava se da mikro revizorske firme imaju najlošije performanse poslovanja po pitanju zaduženosti i profitabilnosti. Male i srednje revizorske firme u cjelokupnom promatranom razdoblju kontinuirano su profitabilne. Također, revizorske firme koje su članice međunarodne mreže bolje se prilagođavaju promjenama na tržištu revizorskih usluga, s obzirom da u promatranom razdoblju imaju kontinuiranu pozitivnu prosječnu stopu povrata na ukupna sredstva. Također, u revizorskim firmama članicama međunarodne mreže radi čak $80 \%$ zaposlenih u sektoru revizije.

Perspektive revizorskih firmi u narednom razdoblju treba da budu okrenute ka jačanju performansi poslovanja, s obzirom na značajna turbulentna i nepovoljna kretanja u razdoblju 2015-2017. godine. Osnovni izvor prihoda ne može više biti prihod od pružanja usluga revizije financijskih izvještaja. Revizorske firme moraju osnažiti performanse poslovanja pružajući usluge iz oblasti nerevizijskih usluga, kao i udruživanjem u međunarodnu mrežu poslovanja. Udruživanje u međunarodnu mrežu poslovanja može dovesti smanjenja konkurencije i povećanja cijene revizijskih usluga kao i do smanjenja kvaliteta revizijskih usluga. Iz navedenih radova na nivou revizijskog tržišta nužno je kontinuirano praćenje performansi poslovanja revizorskih firmi, ali i razine koncentracije revizorskog tržišta.

\section{LITERATURA}

1. Beins, B., McCarthy, M., (2012),Research Methods and Statistics, Pearson Education, Upper Saddle River, New Jersey

2. Goodwin, J., \&Wu, D. (2016). What is the relationship between audit partner busyness and audit quality?Contemporary Accounting Research, 33(1), 341-377.

3. Grant, P. (2010, june 17). Top of the pile. Retrieved October 11, 2011,from http://www.accountancyage.com.

4. Gul, F.A., Ma, S.M.,\& Lai, K. (2017). Busy auditors, partner-client tenure, and audit quality: evidence from an emerging market. Journal of International Accounting Research, 16(1), 83-105.

5. Holm, C., Warming-Rasmussen, B. (2008). An Account of Accountants Audit Regulation and the Audit Profession in Denmark. In R. Quick, S. Turley, \& M. Willekens, Auditing, Trust and Governance - Developing Regulation in Europe (pp. 42-77). Trowbridge: Cromwell Press

6. Jakšić, D., Mijić, K., Vuković, B., (2011), Profesija ovlašćenih revizora u Republici Srbiji. Ekonomske teme, 1, str. 97-109.

7. Jakšić, D., Mijić, K., Andrić, M., (2012), Analysis of Variations in the Performance of Audit Firms in the Republic of Serbia. Economic Annals, 193, str. 71-91. 
8. Kolvereid, L., Amo, B. W. (2019). Growth Intention and Growth in Small Accounting Firms. Administrative Sciences, 9(36), 111.https://doi.org/10.3390/admsci9020036

9. Komora ovlašćenih revizora. (2019). Registar društva za reviziju..https://www.kor.rs/registri_preduzeca.asp (pristupljeno 15. Juna 2019.)

10. Mijić, K., Jakšić, D., Vuković, B. (2014). Koncentracija tržišta revizijskih usluga u Republici Srbiji. Ekonomske teme, 52 (1), 117-130.

11. Raza, A., Wan Husin, W. N. (2019). An explanatory review of audit market concentration and auditor workload in Malaysia. Accounting,

12. Rodić, J., Andrić, M., Vukelić G., Vuković, B., (2017), Analiza finansijskih izveštaja. Ekonomski fakultet Subotica, Subotica.

13. Scoring., (2019), Baza financijskih izveštaja, http://www.scoring.rs/ (pristupljeno 15. Juna 2019.)

14. Sl. glasnik RS, br. 46/06, 111/09 i 99/11 - Zakon o računovodstvu i reviziji

15. Sl. glasnik RS, br. 62/2013 i 30/2018 - Zakon o reviziji 


\title{
Kristina Mijić, PhD
}

Faculty of Economics in Subotica, University of Novi Sad, Subotica, Serbia mijick@ef.uns.ac.rs

\section{Dejan Jakšić, PhD}

Faculty of Economics in Subotica, University of Novi Sad, Subotica, Serbia jaksicd@ef.uns.ac.rs

\section{THE PRACTICE OF FINANCIAL STATEMENT AUDIT IN THE REPUBLIC OF SERBIA - STATE AND PERSPECTIVES}

Received: July 15, 2019

Accepted: October 17, 2019

\section{Review}

\begin{abstract}
The paper analyzes the practice of financial statement audit through an analysis of the performances of audit firms. The survey covered all audit firms operating in the period 2015-2017 in the Republic of Serbia. In order to examine the performances of the audit firms, the profitability, indebtedness and the number of employees were analyzed according to the size of the audit firm and its affiliation to the international network. The results of the survey indicate that micro audit firms have a problem with profitability and indebtedness. From the aspect of belonging to the international network, $80 \%$ of employees are in these companies, which also achieve better profitability.
\end{abstract}

Keywords: audit firms, business performance.

JEL: M42 